\title{
Socioemotional and Cognitive Skills: Its Relation to School Performance in Elementary School
}

\author{
Angélica Maria Ferreira de Melo Castro ${ }^{1}$ \\ José Maurício Haas Bueno ${ }^{1}$ \\ Evandro Morais Peixoto ${ }^{2}$
}

\begin{abstract}
Several constructs shown as good predictors of school performance. However, previous studies have focused only on a part of these predictors, making it difficult to understand their interaction to predict school performance. This study verified the associations (correlations), predictions (linear regressions), and relationship dynamics (network analysis) of variables (intelligence, EI, personality, and executive functions) that predict school performance (Portuguese, mathematics, and general) in children and adolescents in the elementary education. In total, 133 students were submitted to instruments to assess the predictive abilities and performance measures included in this study. Regression analyses showed emotional intelligence and abstract reasoning as the main positive predictors of school performance, and the agreeableness/openness trait as a positive predictor of overall performance and mathematics. The results corroborated by centrality indicators estimated through network analyses. This study advances when considering several variables concurrently.
\end{abstract}

Keywords: academic achievement, cognitive ability, emotional intelligence, elementary education

\section{Habilidades Socioemocionais e Cognitivas: Relações com o Desempenho Escolar no Ensino Fundamental}

\begin{abstract}
Resumo: Diversos construtos têm se mostrado bons preditores do desempenho escolar. Entretanto, estudos anteriores têm se concentrado em apenas parte desses preditores, dificultando a compreensão de sua interação para predição do desempenho escolar. Este estudo teve por objetivo verificar as associações (correlações), predições (regressões lineares) e dinâmicas das relações (análises de rede) de variáveis preditoras (inteligência, IE, personalidade e funções executivas) do desempenho escolar (português, matemática e geral) em crianças e adolescentes no ensino fundamental. Um total de 133 estudantes foram submetidos a instrumentos de avaliação das habilidades preditoras e das medidas de desempenho considerados neste estudo. Por meio de análises de regressão constatou-se a inteligência emocional e o raciocínio abstrato como os principais preditores positivos do desempenho escolar, e o traço de abertura/ amabilidade como preditor positivo do desempenho geral e matemática. Resultados corroborados pelos indicadores de centralidade estimados por meio das análises de rede. Este estudo avança ao considerar diversas variáveis concomitantemente.
\end{abstract}

Palavras-chave: rendimento escolar, aptidão cognitiva, inteligência emocional, ensino fundamental

\section{Habilidades Socioemocionales y Cognitivas: Relaciones con el Rendimiento Escolar en la Escuela Primaria}

\begin{abstract}
Resumen: Se ha demostrado que varios constructos son buenos predictores del rendimiento escolar. Sin embargo, los estudios anteriores se han centrado solo en parte de estos predictores, lo que dificulta comprender su interacción para predecir el rendimiento escolar. Este estudio verificó las asociaciones (correlaciones), predicciones (regresiones lineales) y dinámicas de las relaciones (análisis de redes) de las variables predictoras (inteligencia fluida, inteligencia emocional, rasgos de personalidad y control inhibitorio) del rendimiento escolar (portugués, matemáticas y general) en niños y adolescentes en la escuela primaria. Un total de 133 alumnos fueron sometidos a instrumentos para evaluar las habilidades predictivas y las medidas de rendimiento consideradas en este estudio. Mediante el análisis de regresión se observó la inteligencia emocional y el razonamiento abstracto como los principales predictores positivos del rendimiento escolar, y el rasgo de apertura/amabilidad como un predictor positivo del rendimiento general y de matemáticas. Los resultados fueron corroborados por indicadores de centralidad estimados a través de análisis de redes. Este estudio avanza al considerar varias variables de manera concurrente.
\end{abstract}

Palabras clave: rendimiento escolar, aptitud cognitiva, inteligencia emocional, enseñanza de primer grado

\footnotetext{
${ }^{1}$ Universidade Federal de Pernambuco, Recife-PE, Brazil

${ }^{2}$ Universidade São Francisco, Campinas-SP, Brazil
}

Article derived from the doctoral thesis of the first author under the supervision of the second author, defended in 2019, in the Graduate Program in Cognitive Psychology of the Universidade Federal de Pernambuco. Support: funding from the National Council for Scientific and Technological Development (CNPq) (Protocol No.: 5438573094948885).

Correspondence address: Angélica Maria Ferreira de Melo Castro. Universidade Federal de Pernambuco. Center for Philosophy and Human Sciences. Av. da Arquitetura S/N, Cidade Universitária, Recife-PE, Brazil. CEP 50.740-550. E-mail: angelicamfmcastro@gmail.com
Specialists and public managers worry about the school performance of elementary school students in Brazil. Recent data from the Organisation for Economic Co-operation and Development (OECD, 2018) show that, on average, the performance of Brazilian students in mathematics, reading, and science is in the lower quartile among the 78 countries evaluated. This occurs despite the Brazilian government investing $6.0 \%$ of its gross domestic product (GDP) in education, more than the average of OECD countries that invest 5.5\% (Ministério da Economia, 2018). These data 
suggest the necessity to identify other variables related to school performance, to understand the mechanisms, and to use them for the elaboration of school and curricula practices, and for the orientation of public educational policies.

Intelligence, especially fluid intelligence (Gf), and other constructs treated as socio-emotional abilities, such as emotional intelligence (EI), personality traits and executive functions (EF) are the psychological variables that demonstrated this potential, these constructs are well established in psychology that were proved as predictors of school performance (Gonçalves et al., 2017; Jesus Junior, Silva, Valentini, \& Primi, 2020; MacCann et al., 2020; Soto, 2019). However, it was observed no reports that included these variables in the same study, which would allow us to know their interrelationships and how they contribute to the improvement of school performance. Thus, in order to contribute to the filling of these gaps, this study explored the possible relationships between a set of cognitive and socioemotional variables (independent variables) with school performance (dependent variable) in Brazilian children and adolescents. Such independent variables will be briefly described and discussed below.

\section{Fluid intelligence and socio-emotional skills}

Fluid intelligence (Gf) can be defined as the ability to extract new knowledge from the available information. This process occurs by the combination of a series of more basic capabilities related to perception, attention, and working memory. Perception and attention provide the identification of the parts of a problem and its general and specific characteristics, whereas the working memory keeps this information available to the consciousness and performs the operations of comparison, generation and testing hypotheses, extrapolations, and transformation of information, resulting in a better understanding of the problem and increased chances of solving it (Jesus Junior et al., 2020; Schneider \& McGrew, 2018). Since these processes are requested for school learning, their relationship with grades is well documented. Studies with American students showed that Gf is the leading predictor of performance in reading (Cormier, Bulut, McGrew, \& Singh, 2017) and in mathematics (Cormier, McGrew, Bulut, \& Funamoto, 2017). Similarly, a longitudinal study with Brazilian children showed that Gf is associated with gain in learning (Portuguese and mathematics) (Jesus Junior et al., 2020).

More recently, socio-emotional skills are considered as important as cognitive skills for learning and school performance. Socio-emotional skills allow us to understand and to intervene in how people relate to themselves (emotions and behavioral tendencies), their culture (beliefs, values) and social relationships, and how a person uses this knowledge and skills to make decisions in their life (Schonert-Reichl, Kitil, \& Hanson-Peterson, 2017). They can be accessed through many constructs, including emotional intelligence (EI) (MacCann et al., 2020), personality traits (Soto, 2019), and executive functions (Gonçalves et al., 2017), which are well established in psychology and accepted by specialized entities such as the OECD (2018) and the Collaborative for Academic, Social, and Emotional Learning - CASEL (Brackett, 2018).

Emotional intelligence is a set of skills related to the perception, reasoning, understanding, and regulation of emotions (Mayer, Caruso, \& Salovey, 2016). Skills that have a direct influence on the regulation of goal-driven behaviors (Sanchez-Garcia, Extremera, \& Fernandez-Berrocal, 2016). In the school context, for example, a person with a high level of EI tends to seek an emotional configuration that helps them achieve their learning goals (Brackett, Bailey, Hoffmann, \& Simmons, 2019). A recent meta-analysis study supports this statement by finding that EI is a good predictor of academic performance, and that this occurs especially by the understanding and regulation of emotions (MacCann et al., 2020). Thus, this variable was included in this research.

Another skill set that seems to affect a number of aspects in real life are so-called executive functions. They are defined as a set of cognitive and metacognitive processes that enable the individual to make decisions, to evaluate, and to adapt their behaviors and strategies, seeking to achieve a goal (Diamond \& Ling, 2016). Characterized as the ability to inhibit irrelevant stimuli and allow reflection on decision-making before issuing any response (Diamond $\&$ Ling, 2016), the inhibitory control (IC) is a variable capable of predicting academic performance, both in Brazilian (Gonçalves et al., 2017) and American children (Morgan, Farkas, Hillemeier, Pun, \& Maczuga, 2018). In fact, the IC seems to be the basis of self-regulation and the ability to postpone gratification, allowing, for example, students to stop going out with friends to study. Skills that relate to school performance (Herndon \& Bembenutty, 2017). Thus, the IC was chosen to integrate this study because it is the component that through self-regulation intersects thought and behavior, and, therefore, may be more related to socio-emotional abilities.

Another psychological factor that influences behavior is personality. The model of the five major factors is recognized as a useful taxonomy for the study and investigation of how people can differ in their emotional, interpersonal, experiential, behavioral, and motivational styles in a less situational way. Traditionally, these factors are described as extroversion, agreeableness, conscientiousness, emotional stability (vs neuroticism), and openness to experience (Soto, 2019), besides these traits influence how a person interprets reality. At school, for example, agreeableness can make the students more cooperative with teachers and colleagues, whereas conscientiousness make them organized to fulfill his goals and persists in the face of difficulties. In fact, meta-analysis studies showed conscientiousness as the most prominent predictor of school performance, reaching predictive values comparable to those of cognitive abilities, and remaining predictive even when the correlation is controlled by intelligence measures. Other less prominent predictors are the traits of agreeableness and openness, whose correlations are weaker and not so consistent from one study to another (Poropat, 2009, 2014; Sorić, Penezić, \& Burić, 2017). 
Based on these meta-analytical studies, these variables were also tested as predictors of school performance in this study.

Then, it was observed studies demonstrating the relationship of cognitive aspects (such as intelligence) (Cormier, Bulut et al., 2017; Comier, McGrew et al., 2017) and socio-emotional (Brackett et al., 2019; Diamond \& Ling, 2016; Gonçalves et al. 2017; MacCann et al., 2020; Poropat, 2009) with school performance. However, most studies conducted in this field usually consider only a socioemotional variable (MacCann et al., 2020) and/or a cognitive variable (Cormier, Bulut et al., 2017) per study, which limits the understanding of how these independent variables work when considered concomitantly.

Costa and Fleith (2019), in a systematic review of the literature, concluded that school performance is determined by a multiplicity of cognitive and socio-emotional variables, and that these variables should be measured by standardized instruments in the same study to allow the observation of their interactions in the prediction of school performance. This study aims to contribute to the filling of this gap, besides it searches for new theoretical models that seek to integrate cognitive and socio-emotional processes, such as cold and hot intelligences (Schneider, Mayer, \& Newman, 2016) and the integrated model of differences related to affection (Hughes \& Evans, 2018). All models share the proposal of integration of cognitive and socio-emotional processes to explain the results that people obtain from their efforts to achieve their life goals.

In this sense, the goal was to verify the associations (correlations), predictions (linear regressions), and dynamics of relationships (network analyses) of variables (intelligence, EI, personality, and executive functions) that predict school performance (Portuguese, mathematics, and general) in children and adolescents in elementary school. Thus, this study includes cognitive and socio-emotional variables to explain the result obtained by students in their learning efforts (school performance).

\section{Method}

This is an explanatory research with quantitative methodology. Therefore, in order to achieve the proposed objectives, the following methodological contributions will be operationalized.

\section{Participants}

The sample was obtained by convenience and in a non-probabilistic manner, it is composed of 133 students from a public school in Pernambuco, aged 10-6 years ( mean $=11.77$ years; $S D=1.14$ years), among which $53.4 \%$ were female. Regarding education levels, $12.8 \%$ were in the 5 th grade, $45.9 \%$ in the 6 th grade and $41.4 \%$ in the 7 th grade of elementary school. The inclusion criteria were individuals able to read and to write and demonstrate free and enlightened agreement to participate in the research. Neurological disease diagnosis was the exclusion criterion.

\section{Instruments}

The participants answered to a Socioeconomic Questionnaire to characterize the sample, and to the standardized instruments for assessing intelligence, emotional intelligence, inhibitory control, and personality traits. These instruments are described below.

The Abstract Reasoning Test (Ribeiro, Nakano, \& Primi, 2014) has 12 items for the evaluation of fluid intelligence with analogies. The scores were calculated by the sum of correct answers. The accuracy obtained in the validation study was 0.91 . In this study, the accuracy index $(\alpha=0.607)$ was acceptable for the use in surveys $(\alpha \geq 0.6)$ as recommended by the Brazilian Federal Council of Psychology (2018).

The Social and Emotional or Non-cognitive Nationwide Assessment (SENNA) is an instrument used to assess skills related to the five major personality traits in children and adolescents (Primi, John, Santos, \& De Fruyt, 2017). In this study, a version composed of 59 items was used, divided into two parts; the first was composed of pairs of items in the opposite directions (poles), which were used to correct acquiescent responses, according to the procedures proposed by Soto, John, Gosling and Potter (2008); in the second part, the participants answered 43 self-report items, that were operationalized to describe patterns of behavior in many social spheres, especially in school life. The expected original traits presented insufficient internal consistencies $(<0.5)$. Therefore, a factor analysis was performed resulting in three factors: one that combined the traits of agreeableness/ openness (15 items, $\alpha=0.730$ ), another related to the extroversion trait (12 items, $\alpha=0.730$ ) and the other to the conscientiousness trait ( 6 items, $\alpha=0.712$ ). The scores on these factors were calculated by the mean of the values assigned to the items of each factor.

The Emotional Intelligence Test for Children consists of eight stories representing emotions of joy, sadness, acceptance, anger, fear, surprise, aversion, and anxiety (Nakano \& Zaia, 2012). Following each story, it is presented questions that access skills related to EI: perception, reasoning, understanding, and regulation of emotions. In this study, a reduced version with 28 items was used. After the disposal of six items to improve internal consistency, the instrument was left with 22 items, with a Cronbach's alpha of 0.728 . They were scored according to the consensus and the total score in the test was made by the mean percentages of agreement in the items.

The Hayling Test valuates inhibitory control in children and adolescents (Siqueira et al., 2009). It has 20 sentences (items), subdivided equally into two parts, which must be completed by the respondents. In part A, sentences should be completed with words that are related to the context, whereas in part B the words associated with the context should be avoided. The score that reflected the time difference between the performance of the two tasks $(T B-T A)$ was calculated using the D score, neutralizing the variability of latencies among all participants (Ratcliff, Spieler, \& McKoon, 2000). The authors obtained the reliability indexes by calculating correlations in the test-retest $(r>0.5, p<0.05)$. 
The Cloze Technique is a procedure for evaluating reading comprehension, which, in this study, was used as an indicator of performance in Portuguese. In this process it was selected a text of approximately 200 words, in which one every five words are omitted (Boruchovitch, Santos, \& Oliveira, 2007). Examinees should fill these gaps with the words they deem most appropriate, and one point is obtained when their answer coincides or has the same meaning as the original word. The total score is the sum of the correct answers. The instrument had 32 items, with a KuderRichardson index equal to 0.780 .

Math test. This is an adaptation of the mathematical knowledge test for children and adolescents, whose internal consistency index was 0.88 (Lopes \& Bueno, 2014). However, as this test was not built for students of the 6th and 7 th grade, four items with greater difficulty were introduced. As a result, the instrument had 13 items (problems involving aritmetic operations) and presented a Kuder-Richardson index equal to 0.715 . Due to the correlation from high to moderate $(r=0.48, p<0.01)$ found between the performance tests in Portuguese and mathematics, a general school performance index was calculated by the average of the scores in these tests.

\section{Procedures}

Data collection. To avoid the fatigue of the respondents, the application of the instruments occurred in four collective sessions of 45 minutes and one individual session with 10 minutes, which were scheduled within a period of two weeks, according to the availability of the school. In the first session, the Emotional Intelligence Test was applied; in the second, the SENNA; in the third, the Cloze Test; and the Tests of Abstract Reasoning and mathematics in the last session. The Hayling test was applied individually in the school library. All tests were applied by the main author of this work.

Data analysis. The data were entered in an electronic spreadsheet to carry out Pearson's correlation analyses, multiple linear regression and networks to investigate, respectively, the relationships between the variables, the power of predicting school performance by cognitive and socio-emotional variables and the dynamic relationships between these variables. The correlations from 0.10 to 0.29 were considered low, from 0.30 to 0.49 were moderate and from 0.5 to 1.0 were high (Pallant, 2013).

The regression analyses were preceded by an analysis of the following conditions: sample size and normal distribution of variables, random distribution of residues and absence of multicolinearity. No significant violations of these assumptions were observed; thus, the analyses were conducted with input of the variables by the enter method. The variables that presented $p<0.05$ were considered significant predictors.

Network analyses are expressed by a graph containing nodes, representing the study variables, and rods, representing the connections between the nodes. The arrangement of the nodes in the graph followed these criteria: (a) nodes more correlated with each other are closer; (b) nodes with the highest number of relationships with the other nodes assume a central position on the chart; and (c) the thicknesses of the rods represent the partial correlation, estimated by the LASSO method, thus the thicker rods represent stronger associations between the nodes (Machado \& Bandeira, 2015). The composition of the graphs was performed using the Fruchterman-Reingold algorithm (Epskamp, Borsboom, \& Fried, 2018).

Given the results found in previous studies, it was expected to find a pattern of positive and significant correlations of cognitive and socio-emotional variables with school performance measures. However, the study was more exploratory concerning linear regression and network analyses, in order to observe how the independent variables would relate to each other and to the performance measures (dependent variables). The analyses were performed in the JASP software, version 0.9 (JASP, 2018).

\section{Ethical Considerations}

The project of this research was submitted and approved by the Research Ethics Committee with Human Beings of the Universidade Federal de Pernambuco, Center of Health Sciences, CAAE No. 70873317.9.0000.5208, Opinion No. 2,259,271. Thus, all the recommendations of the National Health Council contained in resolutions 466/2012 and 510/2016 were followed.

\section{Results}

Firstly, it was performed correlation analyses between possible predictor variables (abstract reasoning, inhibitory control, EI, and personality traits) with school performance measures (Portuguese, mathematics, and general). Generally, it was perceived a pattern of positive and significant correlations of possible predictor variables with those of school performance. The exceptions are the inhibitory control and the extroversion trait, presenting nonsignificant correlations with the performance in Portuguese. The measures of intelligence, EI and agreeableness/openness showed a pattern of positive, moderate, and significant correlations with the three measures of school performance, ranging from $0.29(<0.05$, between agreeableness/ openness and Portuguese) to $0.50(<0.01$, performance). On the other hand, the traits of conscientiousness and extroversion, and the inhibitory control presented a pattern of positive, low, and significant correlations with the three measures of school performance, ranging from $0.17(p<0.05$, between conscientiousness and mathematics) to $0.25(<0.05$, between extroversion and mathematics).

Then, it was performed multiple linear regression analyses, aiming to understand the impact of cognitive and socio-emotional variables on the three school performance measures. Predictor variables were those that significantly correlated with the criterion variables. The results can be seen in Table 1. 
Table 1

Regression model for school performance measures

\begin{tabular}{|c|c|c|c|c|c|c|c|c|c|c|c|c|c|c|c|}
\hline \multirow{3}{*}{$\begin{array}{l}\text { Psychological characteristic } \\
\text { (independent) }\end{array}$} & \multicolumn{15}{|c|}{ School Performance (dependent variables) } \\
\hline & \multicolumn{5}{|c|}{ Portuguese } & \multicolumn{5}{|c|}{ Mathematics } & \multicolumn{5}{|c|}{ General } \\
\hline & $B$ & $S_{x}$ & $\beta$ & $t$ & $p$ & $B$ & $S_{x}$ & $\beta$ & $t$ & $p$ & $B$ & $S_{x}$ & $\beta$ & $t$ & $p$ \\
\hline Emotional Intelligence & 0.14 & 0.04 & 0.29 & 3.73 & $0.000^{* * *}$ & 0.06 & 0.02 & 0.21 & 2.74 & $0.007 * *$ & 0.03 & 0.01 & 0.28 & 4.05 & $0.000^{* * *}$ \\
\hline Abstract Reasoning & 0.64 & 0.14 & 0.34 & 4.53 & $0.000^{* * *}$ & 0.36 & 0.08 & 0.34 & 4.71 & $0.000^{* * *}$ & 0.15 & 0.03 & 0.40 & 5.90 & $0.000^{* * *}$ \\
\hline Conscientiousness & 0.68 & 0.43 & 0.12 & 1.60 & 0.113 & 0.09 & 0.24 & 0.03 & 0.39 & 0.700 & 0.11 & 0.08 & 0.09 & 1.27 & 0.207 \\
\hline Amiability/opening & 1.22 & 0.73 & 0.13 & 1.67 & 0.097 & 1.24 & 0.41 & 0.24 & 2.98 & $0.003 * *$ & 0.43 & 0.14 & 0.22 & 3.04 & $0.003 * *$ \\
\hline General extroversion & - & - & - & - & - & 0.21 & 0.40 & 0.37 & 0.58 & 0.578 & -0.01 & 0.13 & 0.01 & 0.53 & 0.958 \\
\hline Inhibitory Control & - & - & - & - & - & 0.84 & 0.40 & 0.16 & 2.12 & $0.036^{*}$ & 0.23 & 0.13 & 0.11 & 1.68 & 0.096 \\
\hline Total R ${ }^{2}(\%)$ & \multicolumn{5}{|c|}{30} & \multicolumn{5}{|c|}{33.4} & \multicolumn{5}{|c|}{43} \\
\hline Abstract Reasoning & 0.77 & 0.15 & 0.41 & 5.24 & $0.000^{* * *}$ & 0.45 & 0.08 & 0.43 & 5.51 & $0.000^{* * *}$ & 0.19 & 0.03 & 0.49 & 6.57 & $0.000^{* * *}$ \\
\hline Conscientiousness & 1.04 & 0.44 & 0.18 & 2.38 & $0.019^{*}$ & 0.48 & 0.24 & 0.15 & 1.95 & 0.054 & 0.23 & 0.09 & 0.20 & 2.65 & $0.009 * *$ \\
\hline Total R ${ }^{2}(\%)$ & \multicolumn{5}{|c|}{20} & \multicolumn{5}{|c|}{20} & \multicolumn{5}{|c|}{27.5} \\
\hline
\end{tabular}

Note. $B=$ beta; $S_{\mathrm{x}}=$ erro padrão; $\beta=$ beta padronizado; $t=$ valor $\mathrm{t} ;{ }^{*} p<0.05 ;{ }^{*} p<0.01 ; * * * p<0.001$.

Generally, EI and abstract reasoning were considered good predictors in all three models presented. Moreover, only the agreeableness/openness trait was considered a significant predictor for overall performance and mathematics, and the inhibition control was significant only for mathematics.

However, it was perceived that the conscientiousness trait, which was significantly correlated with the three performance measures, was no longer a significant predictor in regression analyses. This result draws attention because this trait has been indicating as a variable as significant as intelligence for the prediction of school performance (Poropat, 2009, 2014). Therefore, it was chosen to perform a new multiple linear regression analysis only with the conscientiousness trait and the intelligence measure as predictors of school performance, whose results are at the bottom of Table 2. In these conditions - which simulate the procedure adopted in previous studies-school performance measures presented part of their variance explained by conscientiousness, regardless of the variance explained by abstract reasoning (intelligence measure). The exception occurred only with performance in mathematics, in which the significance index fell to a marginally significant value (between 0.05 and 0.10 ).

Furthermore, in order to obtain data that would allow for a dynamic understanding of the interaction of this study variables, it was performed network analyses for each of the three performance measures. The results of these analyses are presented in Figure 1.

\begin{tabular}{|c|c|c|c|}
\hline Performance in Portuguese & Performance in Mathematics & Overall Performance \\
\hline CI & & \\
\hline
\end{tabular}

Figure 1. Graphical representations of network analyses for school performance measures.

Note. RA: Abstract Reasoning; IE: Emotional Intelligence; CI: Inhibitory control; Amab/Aber: Agreeableness/openness traits; Consc: Conscientious trait; Port: Performance in Portuguese; Mat: Performance in Mathematics; DesEsc: School Performance. 
Figure 1 shows the strong magnitude of the associations that the variables EI and abstract reasoning presented with school performance in Portuguese, mathematics and general performance. It was also emphasized the direct association of the variable agreeableness/openness with the performance in Portuguese, and the indirect association of the traits of conscientiousness and extroversion, through agreeableness/ openness with the performance in Portuguese. In the three network analyses, the variable agreeableness/openness acts as a node-bridge between two sets of variables, one of which is formed by the measures of academic performance, abstract reasoning and EI, and the other set formed by the traits of agreeableness/openness, conscientiousness, and extroversion. Thus, it was observed that the agreeableness/ openness trait presented relevant indicators of centrality in performance analyses in mathematics (connectivity 1.03; proximity 0.92 ; strength 0.68 ), with lower indices than those presented by the performance in mathematics itself (connectivity 1.82 ; proximity 1.25 ; strength 1.82 ). Regarding overall performance, it was obtained similar results, in which the centrality indexes of the variable agreeableness/ openness (connectivity 1.14; proximity 1.13 ; strength 0.30 ) were lower than those verified for the overall performance (connectivity 1.43 ; proximity 1.10 ; strength 1.90 ).

Moreover, the performance in mathematics is directly and moderately affected by the agreeableness/openness trait, but weakly affected by inhibitory control and the extroversion trait. Concerning general performance, it is possible to observe that the stroke of agreeableness/openness is also directly related to the general school performance.

\section{Discussion}

Generally, it was possible to observe that fluid (abstract reasoning) and emotional intelligences, alongside agreeableness/openness trait were, in this order, the main predictors of school performance in this study. This outcome is compatible with those observed in previous studies, except that it was not found the conscientiousness trait as a significant predictor of school performance, as it usually appears in the literature (Cormier, Bulut et al., 2017; MacCann et al., 2020; Sobowale, Ham, Curlin, \& Yoon, 2018; Sorić et al., 2017). Thus, these results support the idea that intentional and flexible control of perception, attention, and memory (fluid intelligence) is important for learning and solving new problems (Schneider et al., 2016). However, this more cognitive function seems to be optimized by two other functions, one more emotional (EI) and the other more relational (the trait of agreeableness/openness).

Previous studies support the idea that the ability to perceive, to reason, to understand, and to regulate emotions related to emotional intelligence keeps the emotional demands - such as distraction, frustration, anxiety, among others - under control, allowing the application of fluid intelligence to learning for longer. For example, it was found that emotionally intelligent people tend to have higher psychological well-being (Sanchez-Garcia et al., 2016), more flexible thinking and aimed at achieving long-term results (Fernandez-Berrocal, Extremera, Lopes, \& RuizAranda, 2014), and interpreting stressful situations more as a challenge than as a threat (Sarrionandia, Ramos-Díaz, \& Fernández-Lasarte, 2018). Thus, it is correct to expect that the results will also apply to children in learning situations, where increased EI should help them interpret school requirements as a challenge, and to maintain focus on achieving long-term results, prolonging their satisfaction with activities for longer.

Consecutively, the agreeableness/openness factor can be understood by the underlying nature of the constructs that compose it. Openness is represented by exploratory behaviors, which goes against the characteristics that De Raad and Schouwenburg (1996) describe as desirable behaviors in a student, because they are positively related to motivation for learning and critical thinking. The operationalization of agreeableness reflects tendencies to act cooperatively and sympathetically, which may be related to the fulfillment of the teacher's instructions, effort and concentration in tasks related to learning (Vermetten, Lodewijks, \& Vermunt, 2001). Therefore, the results obtained in this study seem to suggest that general school performance and mathematics are also associated with behaviors resulting from curiosity and motivation to understand the world, associated with the tendency to act collaboratively and follow the teacher's instructions.

As described, different from what was expected, the conscientiousness trait was not a significant predictor of school performance (Portuguese, mathematics and general). Therefore, explanatory factors can be raised: bias of the measurement instrument, insertion of more predictor variables in the study, and some unknown factor related to the Brazilian cultural context. Regarding the instrument, the conscientiousness factor was represented by items related to performance, such as "I do my tasks in the best way I can" or "I am a dedicated and hardworking student." These behaviors are related to conscientiousness, but the trait as a whole is broader, involves behaviors directed to objectives, persistence in the face of obstacles, organization, discipline, among others (Soto, 2019), whose absence of representation may have made the association non-significant.

Other predictor variables inserted in this study may have altered the unique variance shared between conscientiousness and school performance. One fact to be observed in relation to this is that, surprisingly, the factors of agreeableness and openness joined into one. In previous studies (Poropat, 2009, 2014), these traits appear as predictors of school performance, but, in our study, its predictor power may have been expanded by the combination of factors into only one. Furthermore, the insertion of EI measures and inhibitory control may have contributed to mitigate the effect of the conscientious trait, making it not significant.

Finally, the effect of the cultural context can be suggested due to studies that were taken as a reference, especially the Poropat meta-analyses $(2009,2014)$ that did not include 
Brazilian studies. However, it could be assumed that the way the school environment is organized in Brazil is quite different from other countries. A survey by the OECD (2018), for example, shows that Brazilian teachers spend around $20 \%$ of their class time trying to get the classroom in order. Factors such as this may require personal (socio-emotional) skills different from those of more organized countries. These explanatory possibilities must be investigated in future studies.

Thus, by identifying abstract reasoning, EI, and agreeableness/openness trait as consistent predictors of academic performance, this study supports and corroborates the hypotheses raised by educators and psychologists about the usefulness and potential to integrate the learning of socio-emotional skills in the school curriculum (Brackett et al., 2019). However, this study advances by considering four important psychological constructs (intelligence, emotional intelligence, personality traits, and inhibiting control) as possible predictors of school performance in the same study.

A significant implication of this result is that the three variables contribute independently (directly) to school performance. More broadly, this study identified three psychological aspects that influence school performance and that can be developed through curricular strategies and educational policies: cognitive (Gf), emotional (EI), and social/relational (agreeableness/openness). This suggests that the improvement of the public educational system is directly related to these three aspects, which can be achieved with investment in the training of managers and teachers, favoring the development of curricular strategies that address the socio-emotional aspects alongside the cognitive ones.

In fact, evidence has indicated the significance of the principal's leadership for the construction of a safe and collaborative school environment, within which there is a significant improvement in student performance (Oliveira \& Carvalho, 2018). The results found in this study contribute to the scientific advance by identifying which aspects must be contemplated by educational policies and school actions. These aspects are addressed in programs for the development of socio-emotional skills, such as RULER Approach to Social and Emotional Learning (Brackett et al., 2019), a program based on the theory of emotional intelligence capable of improving grades and the school environment. However, as all research is a clipping of reality, some limitations are noteworthy. One of them was the reduced number of participants, which were also limited to schools in a metropolitan city in Northeastern Brazil, suggesting caution with the generalization of the results found and the need for investigations with larger samples. Another limitation concerns the reduced versions of the instruments not presenting the same dimensionality as the original versions, which is acceptable considering the participants' age group, but also makes it difficult to interpret the results. Nevertheless, the study made it possible to identify cognitive and socio-emotional variables that directly affect school performance, providing significant information to school managers and teachers to direct educational policies and teaching strategies that address these aspects.

\section{References}

Boruchovitch, E., Santos, A. A. A., \& Oliveira, K. L. (2007). Análise da fidedignidade entre dois tipos de pontuação do Teste de Cloze [Reliabilty analises between two types of punctuation of Cloze Technique]. Psicologia em Pesquisa, 1(1), 41-51. doi:10.24879/200700100100444

Brackett, M. A. (2018). The emotional intelligence we owe students and educators. Educational Leadership, 76(2), 12-18. Retrieved from https://www.ascd.org/el/articles/ the-emotional-intelligence-we-owe-students-and-educators

Brackett, M. A., Bailey, C. S., Hoffmann, J. D., \& Simmons, D. N.(2019). RULER:A theory-driven, systemic approach to social, emotional, and academic learning. Educational Psychologist, 54(3), 144-161. doi:10.1080/00461520. 2019.1614447

Conselho Federal de Psicologia. (2018). Resolução No. 009, de 25 de abril de 2018. Estabelece diretrizes para a realização de Avaliação Psicológica no exercício profissional da psicóloga e do psicólogo, regulamenta o Sistema de Avaliação de Testes Psicológicos SATEPSI e revoga as Resoluções No. 002/2003, No. 006/2004 e No. 005/2012 e Notas Técnicas No. 01/2017 e 02/2017 [Establishes guidelines for conducting Psychological Assessment in the professional practice of the psychologist and psychologist, regulates the Psychological Test Assessment System - SATEPSI and repeals Resolutions No. 002/2003, No. 006/2004 and No. 005/2012 and Technical Notes No. 01/2017 and 02/2017]. Retrieved from http://crp11.org.br/ upload/Resolu\%C3\%A7\%C3\%A3o-CFP-n $\%$ C2\%BA09-2018-com-anexo.pdf

Cormier, D. C., Bulut, O., McGrew, K. S., \& Singh, D. (2017). Exploring the relations between Cattell-HornCarroll (CHC) cognitive abilities and mathematics achievement. Applied Cognitive Psychology, 31(5), 530-538. doi:10.1002/acp.3350

Cormier, D. C., McGrew, K. S., Bulut, O., \& Funamoto, A. (2017). Revisiting the relations between the WJ-IV measures of Cattell-Horn-Carroll (CHC) cognitive abilities and reading achievement during the school-age years. Journal of Psychoeducational Assessment, 35(8), 731-754. doi:10.1177/0734282916659208

Resolução $N^{\circ}$ 009, de 25 de abril de 2018. Estabelece diretrizes para a realização de Avaliação Psicológica no exercíResolução $\mathrm{N}^{\mathrm{o}} 009$, de 25 de abril de 2018. Estabelece diretrizes para a realização de Avaliação Psicológica no no exercicio profissional da psicóloga e do psicólogo, regulamenta o Sistema de Avaliação de Testes Psicológicos SATEPSI e revoga as Resoluções $\mathrm{n}^{\circ}$ 002/2003, $\mathrm{n}^{\circ}$ 006/2004 e $n^{\circ} 005 / 2012$ e Notas Técnicas $n^{\circ} 01 / 2017$ e 02/2017. Brasília, DF: Conselho Federal de Psicologia

Costa, B. C. G., \& Fleith, D. S. (2019). Prediction of academic achievement by cognitive and socio-emotional variables: A systematic review of literature. Trends in Psychology, 27(4), 977-991. doi:10.9788/tp2019.4-11 
De Raad, B., \& Schouwenburg, H. C. (1996). Personality in learning and education: A review. European Journal of Personality, 10(5), 303-336. doi:10.1002/(SICI)10990984(199612)10:5<303::AID-PER262>3.0.CO;2-2

Diamond, A., \& Ling, D. (2016). Conclusions about interventions, programs, and approaches for improving executive functions that appear justified and those that, despite much hype, do not. Developmental Cognitive Neuroscience, 18, 34-48. doi:10.1016/j.den.2015.11.005

Epskamp, S., Borsboom, D., \& Fried, E. I. (2018). Estimating psychological networks and their accuracy: A tutorial paper. Behavior Research Methods, 50(1), 195-212. doi:10.3758/s13428-017-0862-1

Fernández-Berrocal, P., Extremera, N., Lopes, P. N., \& Ruiz-Aranda, D. (2014). When to cooperate and when to compete: Emotional intelligence in interpersonal decision-making. Journal of Research in Personality, 49, 21-24. https://doi.org/10.1016/j.jrp.2013.12.005

Gonçalves, H. A., Viapiana, V. F., Sartori, M. S., Hofheinz Giacomoni,C.,Stein,L.M.,\&Fonseca,R.P.(2017).Funções executivas predizem o processamento de habilidades básicas de leitura, escrita e matemática? [Executive functions predict the processing of basic reading, writing, and mathematics skills?]. Revista Neuropsicologia Latinoamericana, 9(3), 42-54. doi:10.5579/rnl.2016.0393

Herndon, J. S., \& Bembenutty, H. (2017). Self-regulation of learning and performance among students enrolled in a disciplinary alternative school. Personality and Individual Differences, 104,266-271. doi:10.1016/j.paid.2016.08.027

Hughes, D. J., \& Evans, T. R. (2018). Putting 'emotional intelligences' in their place: Introducing the integrated model of affect-related individual differences. Frontiers in Psychology, 9, 2155. doi:10.3389/fpsyg.2018.02155

JASP. (2018). Introducing JASP 0.9 [Computer software]. Retrieved from https://jasp-stats.org/2018/06/20/ introducing-jasp-0-9/

Jesus Junior, A. G., Silva, J. A., Valentini, F., \& Primi, R. (2020). Inteligência fluida como preditora do desempenho acadêmico em língua portuguesa e matemática [Fluid intelligence as a predictor of academic performance in portuguese and mathematics]. Psicologia em Pesquisa, 14(esp.), 221-238. doi:10.34019/1982-1247.2020.v14.30398

Lopes, J., \& Bueno, M. (2014). Construção e validação de uma prova de matemática para alunos do $1^{\circ}$ ao $4^{\circ}$ ano de escolaridade [Development and validation of a math test for 1st to 4th grade students]. Psicologia: Reflexão e Critica, 27(3), 434-442. doi:10.1590/1678-7153.201427303

MacCann, C., Jiang, Y., Brown, L. E. R., Double, K. S., Bucich, M., \& Minbashian, A. (2020). Emotional intelligence predicts academic performance: A metaanalysis. Psychological Bulletin, 146(2), 150-186. doi:10.1037/bul0000219
Machado, W. L., \& Bandeira, D. R. (2015). Positive mental health Scale: Validation of the mental health continuum short form. Psico-USF, 20(2), 259-274. doi:10.1590/ 1413-82712015200207

Mayer, J. D., Caruso, D. R., \& Salovey, P. (2016). The ability model of emotional intelligence: Principles and updates. Emotion Review, 8(4), 290-300. doi:10.1177/1754073916639667

Ministério Economia. Tesouro Nacional. (2018). Aspectos fiscais da educação no Brasil [Fiscal aspects of education in Brazil]. Retrieved from https://www. tesourotransparente.gov.br/publicacoes/aspectos-fiscaisda-educacao-no-brasil/2018/30

Morgan, P. L., Farkas, G., Hillemeier, M. M., Pun, W. H., \& Maczuga, S. (2018). Kindergarten children's executive functions predict their second-grade academic achievement and behavior. Child Development, 90(5), 1802-1816. doi:10.1111/cdev.13095

Nakano, T. C., \& Zaia, P. (2012). Criatividade e inteligência emocional em crianças: Um estudo relacional [Creativity and emotional intelligence in children: A relational study]. Psico, 43(3), 388-399. Retrieved from https://revistaseletronicas. pucrs.br/ojs/index.php/revistapsico/article/view/10608

Oliveira, A. C. P., \& Carvalho, C. P. (2018). Public school management, leadership, and educational results in Brazil. Revista Brasileira de Educação, 23, e230015. doi:10.1590/S1413-24782018230015

Organisation for Economic Co-operation and Development. (2018). PISA 2018 Technical Report. Retrieved from https://www.oecd.org/pisa/data/pisa2018technicalreport/

Pallant, J. (2013). SPSS survival manual: A step by step guide to data analysis using IBM SPSS (5th ed.). Berkshire, United Kingdom: McGraw-Hill Education.

Poropat, A. E. (2009). Meta-analysis of the five-factor model of personality and academic performance. Psychological Bulletin, 135(2), 322-338. doi:10.1037/a0014996

Poropat, A. E. (2014). Other-rated personality and academic performance: Evidence and implications. Learning and Individual Differences, 34, 24-32. doi:10.1016/ j.lindif.2014.05.013

Primi, R., John, O. P., Santos, D., \& De Fruyt, F. (2017). SENNA inventory. São Paulo, SP: Ayrton Senna Instituto.

Ratcliff, R., Spieler, D., \& McKoon, G. (2000). Explicitly modeling the effects of aging on response time. Psychonomic Bulletin and Review, 7(1), 1-25. doi:10.3758/bf03210723

Ribeiro, W. J., Nakano, T. C., \& Primi, R. (2014). Validade da estrutura fatorial de uma bateria para avaliação das altas habilidades [Validity of the factor structure of a battery of assessment of high abilities]. Psico, 45(1), 100-109. doi:10.15448/1980-8623.2014.1.13636

Sanchez-Garcia, M., Extremera, N., \& Fernandez-Berrocal, P. (2016). The factor structure and psychometric properties of the Spanish version of the Mayer-Salovey-Caruso Emotional Intelligence Test. Psychological Assessment, 28(11), 1404-1415. doi:10.1037/pas0000269 
Sarrionandia, A., Ramos-Díaz, E., \& Fernández-Lasarte, O. (2018). Resilience as a mediator of emotional intelligence and perceived stress: A cross-country study. Frontiers in Psychology, 9, 2653. doi:10.3389/fpsyg.2018.02653

Schneider, W. J., Mayer, J. D., \& Newman, D. A. (2016). Integrating hot and cool intelligences: Thinking broadly about broad abilities. Journal of Intelligence, 4(1), 1. doi:10.3390/jintelligence4010001

Schneider, W. J., \& McGrew, K. S. (2018). The CattellHorn-Carroll theory of cognitive abilities. In D. P. Flanagan \& E. M. McDonough (Eds.), Contemporary intellectual assessment: Theories, tests, and issues (4th ed., pp. 73-163). New York, NY: Guilford.

Schonert-Reichl, K. A., Kitil, M. J., \& Hanson-Peterson, J. (2017). To reach the students, teach the teachers: $A$ national scan of teacher preparation and social and emotional learning. A report prepared for CASEL. Vancouver, Canada: University of British Columbia.

Siqueira, L. S., Gonçalves, H. A., Pagliarin, K. C., Prando, M. L., Jacobsen, G. M., Moraes, A. L., \& Fonseca, R. P. (2009). Teste Hayling Infantil: Aplicação, registro, pontuação e dados normativos [Children's Hayling Test: Application, registration, scoring and normative data]. In R. P. Fonseca, M. L. Prando, \& N. Zimmermann (Orgs.), Tarefas para avaliação neuropsicológica [Tasks for neuropsychological assessment]: Vol 1. Avaliação de linguagem e funções executivas em crianças [Evaluation of language and executive functions in children] (pp. 66-87). São Paulo, SP: Memnon.

Sobowale, K., Ham, S. A., Curlin, F. A., \& Yoon, J. D. (2018). Personality traits are associated with academic achievement in medical school: A nationally representative study. Academic Psychiatry, 42(3), 338-345. doi:10.1007/s40596-017-0766-5

Sorić, I., Penezić, Z., \& Burić, I. (2017). The Big Five personality traits, goal orientations, and academic achievement. Learning and Individual Differences, 54, 126-134. doi:10.1016/j.lindif.2017.01.024

Soto, C.J.(2019). How replicable are links between personality traits and consequential life outcomes? The life outcomes of personality replication project. Psychological Science, 30(5), 711-727. doi:10.1177/0956797619831612

Soto, C. J., John, O. P., Gosling, S. D., \& Potter, J. (2008). The developmental psychometrics of Big Five SelfReports: Acquiescence, factor structure, coherence, and differentiation from ages 10 to 20. Journal of Personality and Social Psychology, 94(4), 718-737. doi:10.1037/0022-3514.94.4.718

Vermetten, Y. J., Lodewijks, H. G., \& Vermunt, J. D. (2001). The role of personality traits and goal orientations in strategy use. Contemporary Educational Psychology, 26(2), 149-170. doi:10.1006/ceps.1999.1042
Angélica Maria Ferreira de Melo Castro is a Ph.D. in Cognitive Psychology at the Universidade Federal de Pernambuco, Recife-PE, Brazil.

José Maurício Haas Bueno is a Professor at the Universidade Federal de Pernambuco, Recife-PE, Brazil.

Evandro Morais Peixoto is a Professor at the Universidade São Francisco, Campinas-SP, Brazil.

\section{Authors' Contribution:}

All authors made substantial contributions to the conception and design of this study, to data analysis and interpretation, and to the manuscript revision and approval of its final version. All the authors assume public responsibility for content of the manuscript.

\section{Associate Editor:}

Susana Maria Gonçalves Coimbra

Received: Oct. 05, 2020

1st Revision: Feb. 18, 2021

2nd Revision: May. 26, 2021

3rd Revision: Jul. 31, 2021

Approved: Aug. 09, 2021

How to cite this article:

Castro, A. M. F. M., Bueno, J. M. H., \& Peixoto, E. M. (2021). Socioemotional and cognitive skills: Its relations to school performance in elementary school. Paidéia (Ribeirão Preto), 31, e3137. doi:https://doi.org/10.1590/1982-4327e3137 